\title{
Implementasi Sistem Perparkiran Otomatis dengan Menentukan Posisi Parkir Berbasis RFId
}

\author{
FREEON ALKAPON IMBIRI' ${ }^{1}$, NANDANG TARYANA ${ }^{2}$, DECY NATALIANA ${ }^{3}$
}

\author{
1,2,3Teknik Elektro Institut Teknologi Nasional (ITENAS) Bandung \\ Email:freeonalkapon@yahoo.co.id
}

\begin{abstract}
ABSTRAK
Apartemen merupakan salah satu tempat tinggal yang ideal di kota metropolitan yang menyediakan banyak fasilitas bagi penghuninya. Salah satu fasilitas tersebut adalah tersedianya area parkir yang memadai dan nyaman bagi penghuni yang memiliki kendaraan, pada kenyataannya saat ini sistem perparkiran yang digunakan masih bermasalah. Masalah yang ditimbulkan dalam sistem perparkiran adalah kurangnya informasi mengenai lahan parkir yang kosong serta penempatan kendaraan yang tidak sesuai sehingga sering kali pemilik kendaraan membutuhkan waktu yang lama untuk sekedar menemukan tempat parkir yang kosong. Berdasarkan hal itu diperlukan sebuah sistem monitoring parkir yang memudahkan pengendara kendaraan yang hendak parkir. Tujuan penelitian ini adalah merancang dan merealisasikan model sistem monitoring perparkiran dengan fasilitas pemilihan area parkir menggunakan Teknologi RFId. Perangkat lunak yang digunakan pada sistem ini dirancang dengan menggunakan bahasa C\#. Pada sistem ini proses pengambilan data secara kontinyu menggunakan mikrokontroler Atmega16 sebagai komponen kendali utamanya. Pengujian dilakukan secara simulasi pada miniatur perparkiran. Hasil pengujian model sistem perparkiran dapat menampilkan kondisi dari masing-masing area parkir yang ditampilkan pada display. Sistem pengambilan data secara kontinyu menggunakan kartu RFId sistem ini dapat menggantikan operator. Sensor cahaya (LED dan LDR) akan berlogika 1 jika ada mobil yang lewat.
\end{abstract}

Kata kunci : Parkir, RFId, LED, LDR, Mikrokontroler, Atmega16, Microsoft Acess, C\#.

\begin{abstract}
Apartment is an ideal place of living in a big city, it provides a lot of facilities .One of apartment facilities is a parking lot that are adequate and comfortable for its occupants who have vehicles. Problems caused in the parking system is the lack of information regarding the parking lot is empty and the placement of the vehicle that is not in accordance with the wishes so that often the owner of the vehicle takes a long time to just find an empty parking space. Based on that required a monitoring system parking facilitate motorists want to park. The purpose of this study was to design and to make a realization of parking monitoring system where could be choosen the parking lot with RFId Technology. The software used in the system is designed using the $C$ \# language. In this system, the process to taking the data with microcontroller Atmega 16 as a main controller. The trial for this system done with simulation in a miniatur parking area. The result of the trial is the system can display about status of parking area. Continuous data retrieval system using RFID cards, and the system can replace the operator. The light sensor (LED AND LDR) to logic 1 if no passing cars.
\end{abstract}

Keywords:Parking, RFId, LED, LDR, Microcontroler, Atmega16, Microsoft Acess, C\# 


\section{PENDAhUlUAN}

Apartemen merupakan salah satu tempat tinggal yang ideal di kota metropolitan yang menyediakan banyak fasilitas bagi penghuninya. Salah satu fasilitas tersebut adalah tersedianya area parkir yang memadai dan nyaman bagi penghuni yang memiliki kendaraan, pada kenyataannya saat ini sistem perparkiran yang digunakan masih bermasalah. Masalah yang ditimbulkan dalam sistem perparkiran adalah kurangnya informasi mengenai lahan parkir yang kosong serta penempatan kendaraan yang tidak sesuai sehingga sering kali pemilik kendaraan membutuhkan waktu yang lama untuk sekedar menemukan tempat parkir yang kosong. Berdasarkan hal itu diperlukan sebuah sistem monitoring parkir yang memudahkan pengendara kendaraan yang hendak parkir. Tujuan penelitian ini adalah merancang dan merealisasikan model sistem monitoring perparkiran dengan fasilitas pemilihan area parkir menggunakan Teknologi RFId. RFId Merupakan teknologi otomatis identifikasi yang paling murah untuk memudahkan penyebaran informasi menjadi lebih cepat dan akurat. Penerapan teknologi RFId ini yang digunakan oleh penulis adalah untuk diterapkan dalam sistem parkir terkomputerisasi sehingga memudahkan dalam hal pengenalan kendaraan dan otomatisasi data. Dalam sistem ini telah diterapkan sistem pemilihan posisi parkir. Secara teori pada penelitian Landt dikatakan bahwa RFid sudah merupakan bagian yang terintegerasi dalam kehidupan sehari-hari, yang dapat meningkatkan produktifitas dan kenyamanan. Dikatakan juga bahwa RFid sangat berguna bagi peningkatan produtifitas industri serta sangat berguna untuk pegembangan perangkat lunak (Landt, 2005). Menurut Roy dalam penelitiannya mengatakan bahwa RFId bukan hanya sekedar pengganti barcode. RFId juga memberikan berbagai macam fitur yang tidak diberikan barcode seperti keamanan, cara pembacaan yang tidak harus secar langsung. Want mengatakan bahwa nantinya RFId akan digunakan secara global sebagai metode identifikasi otomatis (Landt, 2004). Menurut Nath dalam penelitiannya menyimpulkan bahwa RFId merupakan teknologi identifikasi otomatis yang murah, dan dapat diimplementasikan pada sistem atau alat yang relatif murah. Salah satu masalah di kota-kota besar adalah parkir. Jumlah kendaraan bertambah pesat, namun tidak ada tempat yang cukup menampungnya (Nath, 2006). Gambar 1 memperlihatkan klasifikasi identifikasi otomatis

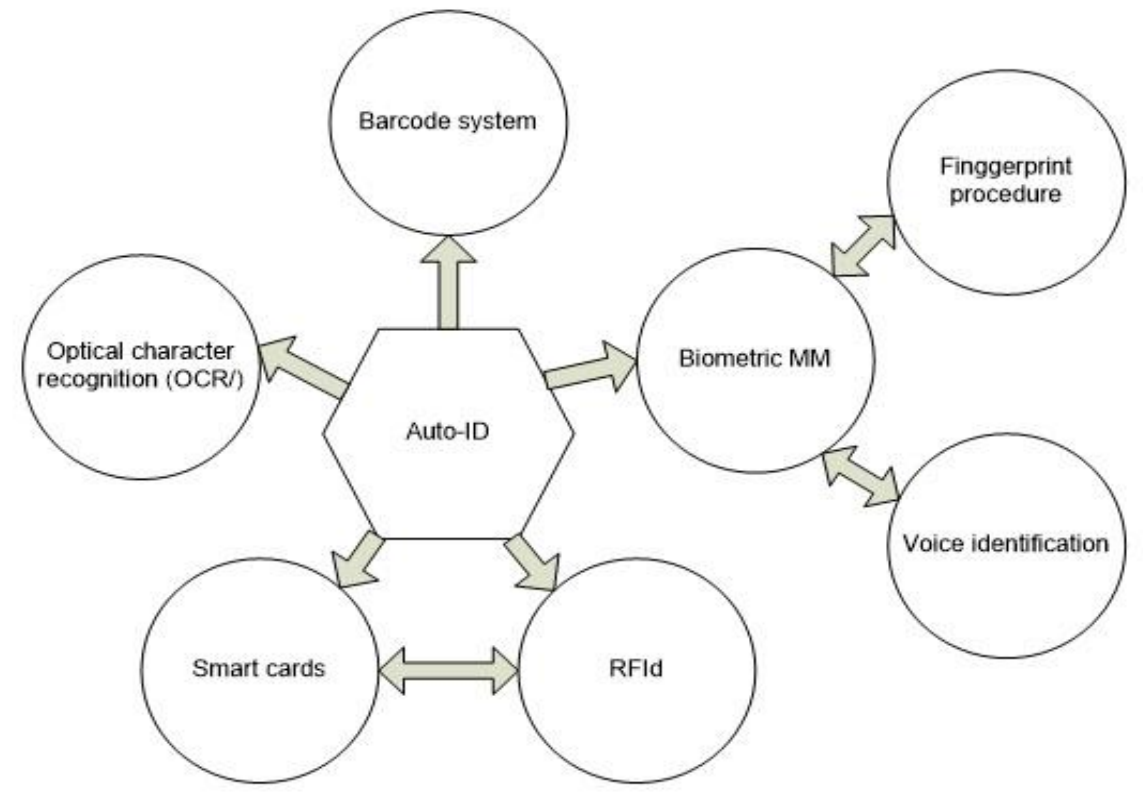

Gambar 1. Klasifikasi identifikasi otomatis 
Berikut ini beberapa penelitian yang terkait dengan perancangan sistem Radio Frequency Identification (RFId).

Menurut darwin pada jurnalnya yang berjudul "System manajemen parkir menggunakan teknologi RFid" menyatakan bahwa penelitian ini menghasilkan sistem manajemen parkir menggunakan teknologi Radio Frequency and Identification (RFID). Teknologi RFID menggunakan gelombang radio untuk mengidentifikasi orang atau benda secara otomatis menggunakan tag. Proses identifikasi dilakukan dengan menyimpan nomor seri yang mengidentifikasi seseorang atau objek melalui microchip yang terpasang pada antena chip yang kemudian mengirimkan informasi data identifikasi kepada reader dan mengubah gelombang radio (gelombang analog) menjadi informasi digital dan diteruskan ke komputer agar dapat diolah. Media yang digunakan dalam bentuk kartu tanda parkir. Dengan pembangunan sistem parkir menggunakan Radio Frequency and Identification (RFId), maka diubah sistem parkir manual ke arah sistem komputerisasi yang menyediakan banyak fasilitas dan kontrol yang lebih efektif dan efisien (Darwin, 2014).

Menurut Irda pada jurnalnya yang berjudul "System parkir otomatis menggunakan RFid berbasiskan mikrokontroller" menyatakan bahwa sistem parkir otomatis adalah sebuah sistem otomatis parkir mobil yang di mana kita tidak perlu membuang-buang waktu dalam mencari tempat parkir mobil kosong. Hanya dengan RFId tag sentuh, maka mobil akan diparkir secara otomatis di tempat yang telah ditentukan sebelumnya. Alat ini menggunakan mikrokontroler AT89S51 sebagai otak pengendali, kartu RFID sebagai identifikasi pemilik mobil, dan beberapa lift dasar yang dibuat dan dirancang sedemikian rupa bisa bergerak bebas dan pada dasarnya digerakkan oleh motor listrik (Irda, 2009).

Menurut boby di majalah ilmiah UNIKOM yang berjudul "Perbaikan sistem Parir Kendaraan Bermotor di lingkungan Universitas Komputer Indonesia dengan menggunakan RFid dan database" menyatakan bahwa Teknologi RFId (Radio-Frequency Identification) merupakan teknologi yang diharapkan dapat menggantikan barcode optik di masa yang akan datang. Kelebihan RFId dibandingkan dengan barcode konvensional antara lain RFId dapat melakukan many-to-many communication yang dapat diartikan banyak reader dapat membaca satu tag, maupun satu reader dapat membaca banyak tag, serta menggunakan transmisi data secara wireless dibandingkan dengan barcode konvensional yang menggunakan optic. Dengan adanya penggunaan RFID untuk sistem parkir, diharapkan dapat membuat sistem parkir yang ada di Unikom saat ini dapat berjalan lebih baik, aman dan nyaman (Kurniawan, 2014).

Menurut Sitanaya pada tugas akhirnya yang berjudul "sistem parkir prabayar menggunakan RFid untuk pusat perbelanjaan" menyatakan bahwa gagasan untuk membuat sistem parkir yang lebih baik, yakni sistem prabayar dengan teknologi RFID supaya diperoleh waktu transaksi yang cepat, efisien dan keamanan yang lebih baik. Dengan Borland Delphi 7 dan Microsoft Access 2000 telah dibangun suatu sistem parkir prabayar yang mempunyai faktor keamanan tinggi dan efisien serta cepat. Karena sistem dapat bekerja secara otomatis dan laporan keuangan yang jelas. Sistem ini menggunakan tag RFID sebagai kartu parkir dan webcam untuk mengambil gambar mobil dan pengemudinya (saat sensor RFID mendeteksi tag di pintu masuk). Informasi tersebut akan diambil dan dikirimkan ke komputer server. Bila informasi tersebut berbeda saat kendaraan akan keluar, maka kendaraan tidak diperbolehkan keluar tanpa suatu prosedur administrasi dan keamanan (Sitanaya, 2005). 
Berdasarkan beberapa kajian pustaka yang telah penulis lakukan, maka penelitian ini bertujuan untuk membuat sistem perparkiran secara otomatis dengan menentukan posisi parkir menggunakan teknologi RFId pada suatu apartemen.

\section{PERANCANGAN DAN REALISASI SISTEM PARKIR RFID}

\subsection{Gambaran Umum Sistem}

Sistem perparkiran yang dirancang untuk mengatur dan memudahkan pengelolaan lahan parkir, mengkomputerisasi input data base nama serta informasi apartemen merupakan tempat tinggal yang ideal di kota metropolitan yang besar dan ramai, namun memiliki area parkir yang tidak efektif karena area parkir yang disediakan biasanya berada di basement atau disekililing area apartemen tersebut. Karena letak tempat parkir tersebut letaknya jauh maka mobil yang hendak memarkirkan kendaraannya kurang mendapatkan informasi mengenai status area parkir serta letak posisi parkir yang masih kosong di perlukan dan membuat sistem parkir otomatis yang memanfaatkan teknologi RFId. Akibat dari kurangnya informasi yang didapat, seringkali para pengguna mobil perlu memakan waktu yang lama untuk sekedar menemukan tempat yang kosong, dan cenderung memarkirkan kendaraannya di sembarang tempat. Untuk itu dibuat suatu sistem perparkiran yang dapat mampu mengatasi masalah yang sering terjadi pada area parkir.

\subsection{Perancangan dan Realisasi Perangkat Keras (Hardware)}

Spesifikasi dari sistem alat ini adalah sebagai berikut:

1. Akses masuk lahan parkiran menggunakan kartu RFId

2. Tag RFId menggunakan ID-12 yang bekerja pada frekuensi $125-134 \mathrm{Khz}$

3. Komunikasi antara $P C$ menggunakan kabel UTP model Cross

4. Komunikasi dari $\angle C D$ ke mikro menggunakan kabel serial

5. Komunikasi pengiriman data dari kamera ke $p c$ menggunakan kabel sepanjang \pm 1 meter

6. Komunikasi pengiriman data dari $P C$ ke mikrokontroler menggunakan kabel serial dengan panjang 30 centi meter.

7. Sensor LDR mampu menangkap pancaran cahaya dari sensor LED $\pm 30 \mathrm{~cm}$

8. Motor servo mampu berputar sampai $360^{\circ}$, dimana pada palang pintu digunakan sudut $0^{\circ}-90^{\circ}$

Berdasarkan spesifikasi sistem yang diinginkan, maka blok diagram sistem yang dirancang dapat dilihat pada Gambar 2.

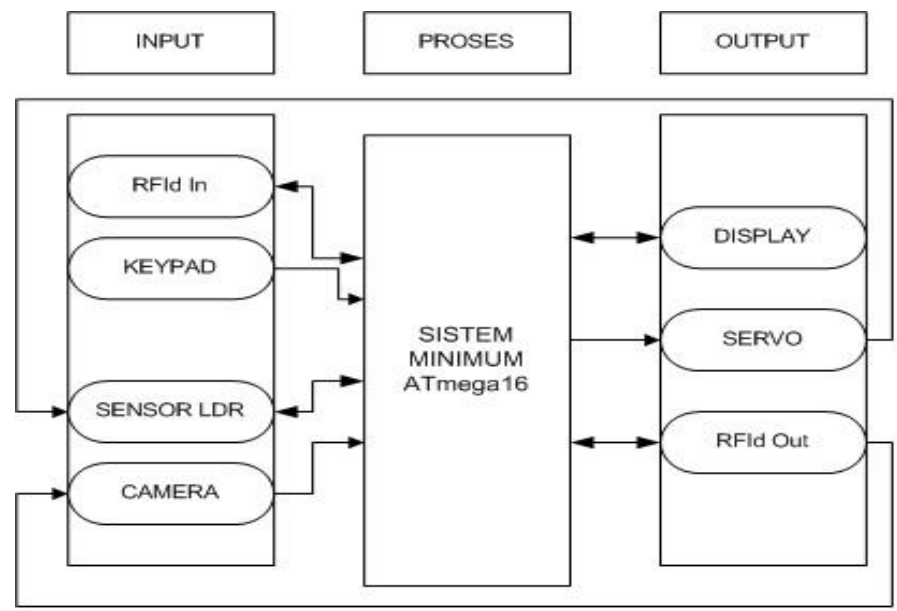

Gambar 2.Blok Diagram Sistem Secara Umum 
Berdasarkan blok diagram pada Gambar 2 dapat dilihat bahwa bagian input terdiri dari 3 input utama (RFId, Numpad dan LDR dan LED) dan 3 output utama (Servo, Displaydan Camera File) yang terhubung langsung ke Sistem Mikrokontroler.

Bagian input sistem ini terdiri dari :

1. RFId

2. Numpad

3. Sensor LDR dan LED

Bagian output sistem ini terdiri dari :

1. Servo

2. Display

3. Camera file

Gambar 3 menunjukkan gambar arsitektur denah parkir yang akan dirancang dalam sebuah miniatur sistem perparkiran.

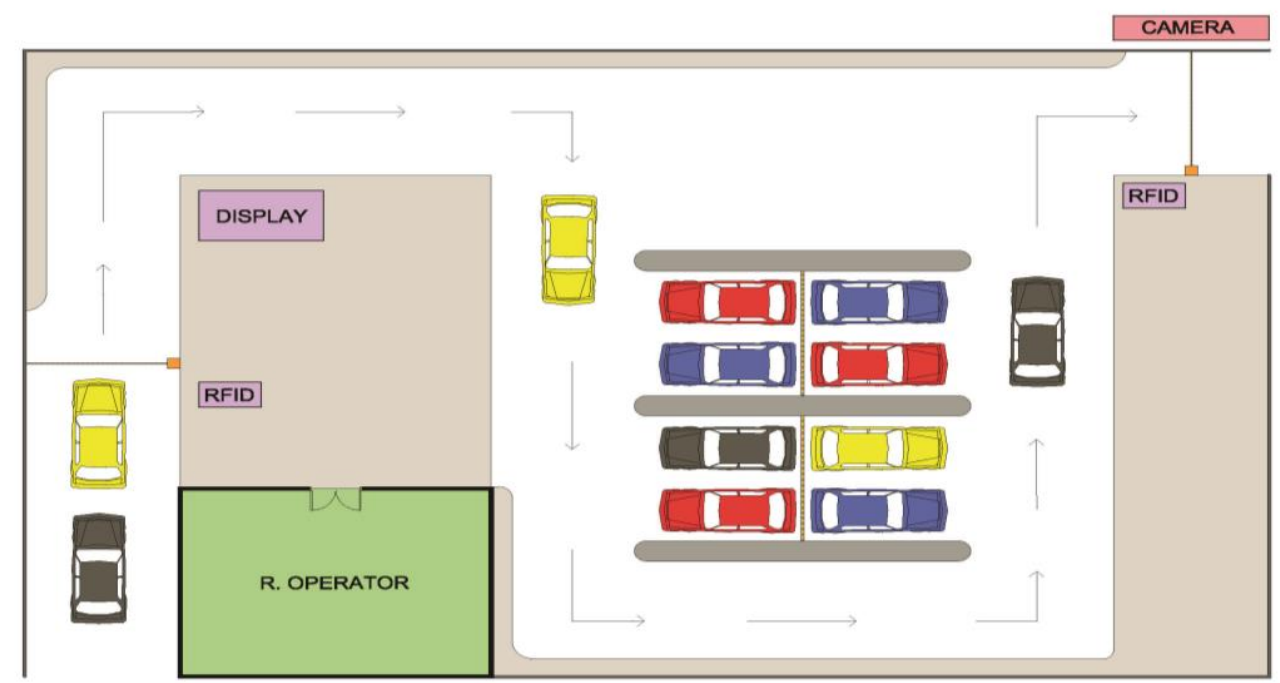

Gambar 3. Arsitektur denah parkir

\subsection{Perancangan dan Realisasi Perangkat Lunak (Software)}

Spesifikasi perangkat lunak yang dirancang adalah:

1. Perancangan dan realisasi perangkat lunak menggunakan bahasa Atmel studio.

2. Perangkat lunak yang direalisasikan dengan menggunakan sensor LDR, RFId, Numpad, Servo, Display LCD serta Mikrokontroler.

3. Perangkat lunak dirancang dan direalisasikan untuk melakukan pemilihan posisi lahan parkir, mencatat segala informasi mengenai pengakses lahan parkir yang disimpan dalam database.

4. Proses download programing ke mikrokontroler menggunakan USB Flasher.

Gambar 4 menunjukkan bentuk flowchart sistem yang dirancang dan direalisasikan untuk diubah ke dalam bentuk bahasa pemrograman $C \#$. 

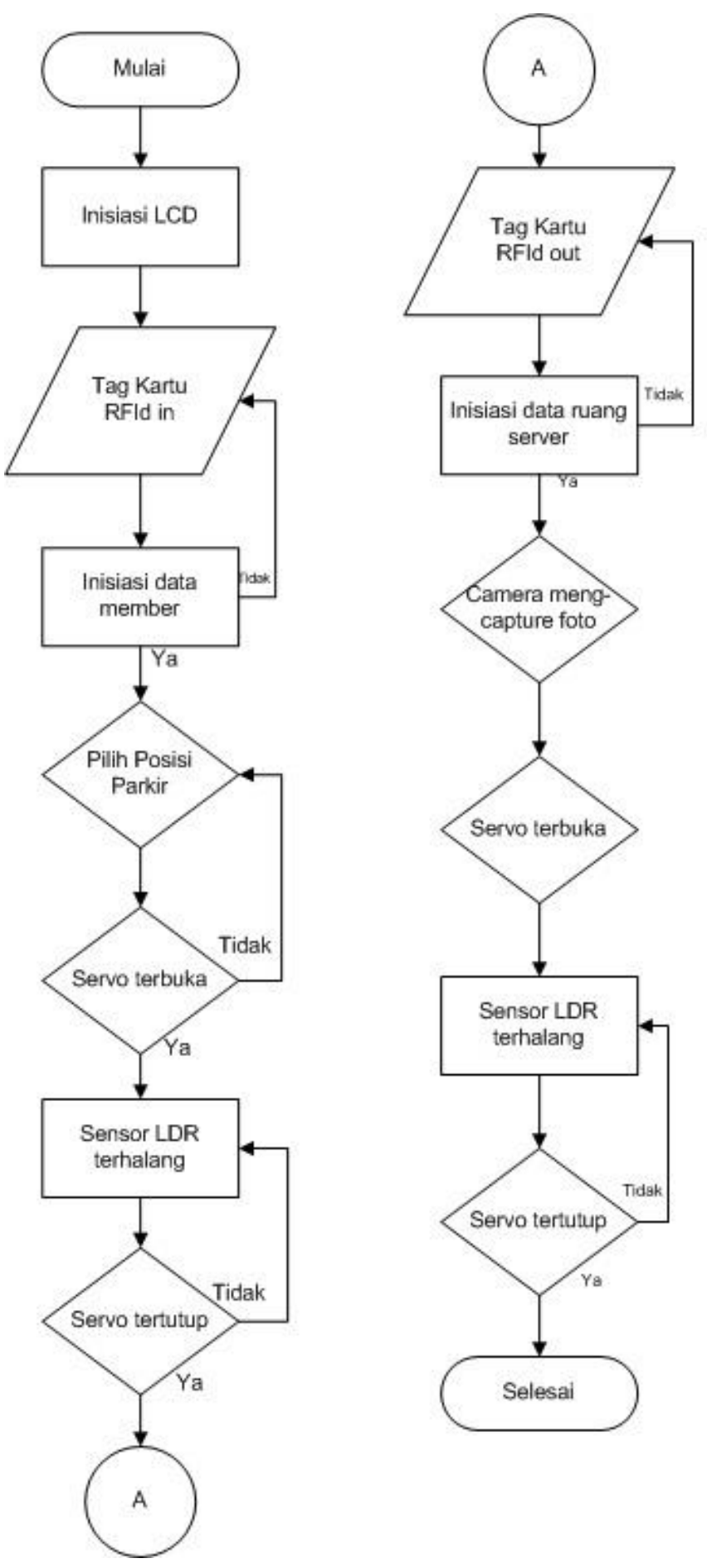

\section{Gambar 4. Flowchart Program secara umum}

\subsubsection{Deskripsi Kerja Sistem}

1. Pada saat kendaraan masuk pengemudi kendaraan mengeluarkan dan mendekatkan kartu tag RFIdreader yang terletak pada loket masuk.

2. Status area parkir ditunjukkan pada tampilan display, warna merah menunjukan area parkir yang masih kosong dan siap dipilih, dan warna hijau menunjukan area parkir yang telah diisi. Pengguna kendaraan memilih area parkir sesuai dengan yang diinginkan setelah menekan angka pada keypad sebagai pemilihan posisi parker. Setelah memilih posisi parkir maka layar LCD yang menunjukkan lokasi parkir berwarna merah akan 
berubah menjadi warna hijau menandakan lokasi yang sudah dipilih oleh pengakses parkir.

3. Setelah dilakukan pemilihan lokasi parkir saat masuk, maka palang pintu akan terbuka dan kendaraan akan memasuki area parkir. Kendaraan akan melewati sensor LDR dan LED yang akan kembali menutup palang pintu.

4. Saat pengguna sudah mengakses area parkir, maka status dari pemegang kartu sudah tercatat pada LCD serveryang berada di ruang operator.

5. Data yang tersimpan di ruang operator server ialah data pengguna kartu yang sudah mendaftarkan atau mengisi pendaftaran pada awal.

6. Saat pengguna kendaraan menuju pintu keluar, pengguna kendaraan harus kembali mendekatkan kartu RFId sebagai alat pengakses keluar parkiran yang akan membuka palang pintu dan mencatat informasi database pada server yang berada di ruang operator. Tampilan LCD pada pintu masuk yang menunjukkan lokasi parkir yang digunakan pengguna parkir dari berwarna hijau terisi akan kembali berwarna merah yang berarti kosong.

\section{HASIL PENGUJIAN DAN ANALISIS}

\subsection{Pengujian Perangkat Keras (Hardware)}

\subsubsection{Pengujian Rangkaian Input Sensor pada Palang Pintu}

Pengujian rangkaian input ini dilakukan dengan cara mengukur tegangan output tiap-tiap blok sistem pada saat sensor tidak terhalang oleh kendaraan dan pada saat sensor terhalang oleh kendaraan. LDR disini dipasang seri berfungsi sebagai pembagi tegangan. Intensitas cahaya yang mengenai permukaan LDR akan mempengaruhi output dari pembagi tegangan tersebut. Pengukuran tersebut menggunakan multimeter digital. Tabel 1 menunjukan hasil Output LDR sensor pada pintu masuk.

Tabel 1. Output Sensor Pada Pintu Masuk

\begin{tabular}{|c|c|c|}
\hline \multirow{2}{*}{ Pengukuran } & \multicolumn{2}{|c|}{ Tegangan saat } \\
\cline { 2 - 3 } & Ada cahaya & Tidak ada cahaya \\
\hline 1 & $1,068 \mathrm{~V}$ & $4,22 \mathrm{~V}$ \\
\hline 2 & $1,135 \mathrm{~V}$ & $4,20 \mathrm{~V}$ \\
\hline 3 & $1,101 \mathrm{~V}$ & $4,19 \mathrm{~V}$ \\
\hline 4 & $1,065 \mathrm{~V}$ & $4,28 \mathrm{~V}$ \\
\hline 5 & $1,088 \mathrm{~V}$ & $4,30 \mathrm{~V}$ \\
\hline 6 & $1,101 \mathrm{~V}$ & $4,19 \mathrm{~V}$ \\
\hline 7 & $1,065 \mathrm{~V}$ & $4,28 \mathrm{~V}$ \\
\hline 8 & $1,088 \mathrm{~V}$ & $4,30 \mathrm{~V}$ \\
\hline 9 & $1,101 \mathrm{~V}$ & $4,19 \mathrm{~V}$ \\
\hline 10 & $1,065 \mathrm{~V}$ & $4,28 \mathrm{~V}$ \\
\hline
\end{tabular}


Tabel 2 menunjukan hasil output sensor LDR pada pintu keluar, pengukuran tersebut menggunakkan multimeter digital.

Tabel 2. Output Sensor Pada Pintu Keluar

\begin{tabular}{|c|c|c|}
\hline \multirow{2}{*}{ Pengukuran } & \multicolumn{2}{|c|}{ Tegangan saat } \\
\cline { 2 - 3 } & Ada cahaya & Tidak ada cahaya \\
\hline 1 & $1,014 \mathrm{~V}$ & $4,36 \mathrm{~V}$ \\
\hline 2 & $1,127 \mathrm{~V}$ & $4,23 \mathrm{~V}$ \\
\hline 3 & $1,136 \mathrm{~V}$ & $4,16 \mathrm{~V}$ \\
\hline 4 & $1,077 \mathrm{~V}$ & $4,30 \mathrm{~V}$ \\
\hline 5 & $1,058 \mathrm{~V}$ & $4,42 \mathrm{~V}$ \\
\hline 6 & $1,101 \mathrm{~V}$ & $4,19 \mathrm{~V}$ \\
\hline 7 & $1,065 \mathrm{~V}$ & $4,28 \mathrm{~V}$ \\
\hline 8 & $1,088 \mathrm{~V}$ & $4,30 \mathrm{~V}$ \\
\hline 9 & $1,101 \mathrm{~V}$ & $4,19 \mathrm{~V}$ \\
\hline 10 & $1,065 \mathrm{~V}$ & $4,28 \mathrm{~V}$ \\
\hline
\end{tabular}

Dari hasil pengukuran didapat variasi tegangan saat sensor dalam keadaan terhalang dan dalam keadaan tidak terhalang. Dari Tabel 1 didapat tegangan terbesar 1,135 Volt. Sensor dalam keadaan terhalang menunjukan sensor akan memberikan inputan Low Voltage pada mikrokontroler, sedangkan untuk sensor yang terhalang akan memberikan input High Voltage pada mikrokontroler.

\subsubsection{Pengujian LDR terhadap tingkat cahaya}

Pengukuran dilakukan menggunakan lux meter dengan cara penambahan lampu senter sebagai acuan tingkatan cahaya dikarenakan jika menggunakan lampu pijar pengaruh terhadap sensor LDR tidak nampak. Hasil pengukuran dapat dilihat pada Tabel 3.

Tabel 3. Pengujian LDR terhadap tingkat cahaya

\begin{tabular}{|c|c|c|c|c|}
\hline $\begin{array}{c}\text { Percobaan } \\
\text { sensor LDR }\end{array}$ & $\begin{array}{c}\text { Tingkat } \\
\text { cahaya } \\
\text { (Lux) }\end{array}$ & $\begin{array}{c}\text { Tahanan } \\
\text { LDR (k } \boldsymbol{\Omega})\end{array}$ & $\begin{array}{c}\text { Tegangan } \\
\text { output }\end{array}$ & $\begin{array}{c}\text { Jarak lampu \& } \\
\text { LDR (cm) }\end{array}$ \\
\hline \multirow{3}{*}{ SENSOR In } & 37 & 45 & 0,3 & 3 \\
\cline { 2 - 5 } & 43 & 38 & 0,5 & 7 \\
\cline { 2 - 5 } & 54 & 27 & 0,9 & 9 \\
\hline \multirow{3}{*}{ SENSOR Out } & 66 & 19 & 1,2 & 13 \\
\cline { 2 - 5 } & 79 & 10 & 1,4 & 17 \\
\cline { 2 - 5 } & 97 & 7,8 & 1,6 & \\
\hline
\end{tabular}




\subsubsection{Pengujian LDR Terhadap Sudut Datang Cahaya}

Pengukuran dilakukan menggunakan lux meter dengan cara penambahan lampu senter sebagai acuan tingkatan cahaya dikarenakan jika menggunakan lampu pijar pengaruh terhadap sensor LDR tidak nampak. Hasil pengukuran dapat dilihat pada Tabel 4.

Tabel 4. Pengujian Pendeteksi Cahaya berdasarkan Sudut

\begin{tabular}{|c|c|c|}
\hline $\begin{array}{c}\text { Sudut } \\
\mathbf{a} \\
\left({ }^{\circ}\right)\end{array}$ & $\begin{array}{c}\text { Tegangan keluaran } \\
\text { LDR } \\
(\text { volt) }\end{array}$ & $\begin{array}{c}\text { Tahanan } \\
\text { LDR } \\
\text { (desimal) }\end{array}$ \\
\hline 30 & 4,02 & 205 \\
\hline 40 & 3,69 & 188 \\
\hline 50 & 3,61 & 184 \\
\hline 60 & 3,55 & 181 \\
\hline 70 & 3,33 & 179 \\
\hline 80 & 2,90 & 170 \\
\hline 90 & 2,73 & 148 \\
\hline
\end{tabular}

\subsection{Pengujian Perangkat Lunak (Software)}

Pengujian perangkat lunak dibagi kedalam beberapa bagian, yaitu pengujian perangkat lunak untuk rangkaian keypad, pengujian untuk rangkaian motor servo dan pengujian perangkat lunak pada sistem database.

\subsubsection{Pengujian Perangkat Lunak untuk Sensor LDR}

Pengujian ini dilakukan untuk mengetahui apakah sensor LDR dapat terhubung dengan interface. Ada beberapa pengujian yang dilakukan yaitu pengujian dengan kedua sensor pada area parkir tidak terhalang oleh apapun, pengujian satu sensor terhalang dan yang satunya lagi tidak, dan pengujian kedua sensor terhalang. Untuk hasil pengujian dapat dilihat pada Tabel 5. Gambar 5 menunjukkan keadaan portal saat terhalang dikarenakan belum ada proses pengiriman data dari sistem mikrokontroler.

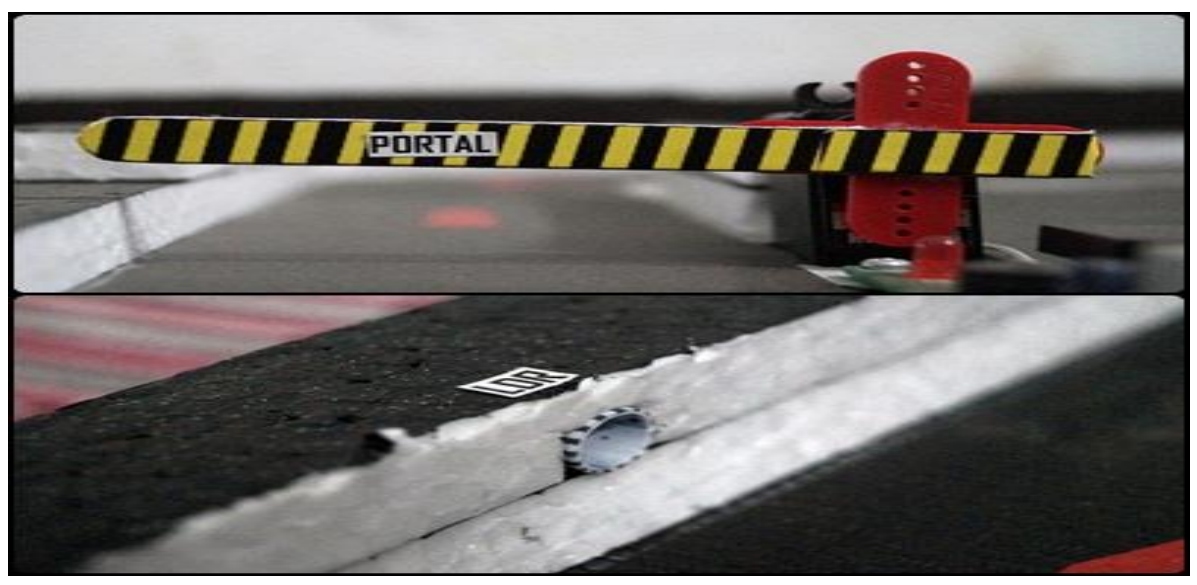

Gambar 5. Keadaan Portal saat terhalang

Tabel 5. Hasil Pengujian Perangkat Lunak Untuk Sensor

\begin{tabular}{|c|c|c|c|c|}
\hline No & Portal in & Portal in & Portal out & Portal out \\
\hline 1. & Terhalang & Tertutup & Terhalang & Tertutup \\
\hline 2. & Tidak terhalang & Terbuka & Tidak terhalang & Terbuka \\
\hline
\end{tabular}


Dari hasil pengujian diperoleh untuk dapat menutup palang pintu pada saat mobil masuk atau keluar area parkir. Keadaan sensor harus terhalang agar output dari sensor yang terhalang tersebut dapat di komunikasikan kembali ke mikrokontroler untuk menutup palang pintu setelah mobil melintasi pintu masuk dan keluar area parkir.

\subsubsection{Pengujian Perangkat Lunak Untuk Keypad}

Pengujian ini dilakukan untuk mengetahui apakah keypad dapat terhubung dengan interface yang dibuat. Ada beberapa hasil yang akan dilihat dari pengujian ini yaitu warna dari area parkir setelah keypad ditekan atau dipilih sesuai dengan area yang ingin diisi dan apakah keypad mampu memberi perintah melalui mikrokontroler. Untuk hasil pengujian dapat dilihat pada Tabel 6.

Tabel 6. Hasil Pengujian Perangkat Lunak Keypad

\begin{tabular}{|c|c|c|c|c|}
\hline No. & Keypad & $\begin{array}{c}\text { Warna Area Parkir } \\
\text { sebelum ditekan }\end{array}$ & $\begin{array}{c}\text { Warna Area } \\
\text { Setelah Dipilih }\end{array}$ & $\begin{array}{c}\text { Status Area } \\
\text { Parkir }\end{array}$ \\
\hline 1. & 01 & Merah & Hijau & Berhasil \\
\hline 2. & 05 & Merah & Hijau & Berhasil \\
\hline 3. & 11 & Merah & Hijau & Berhasil \\
\hline 4. & 20 & Merah & Hijau & Berhasil \\
\hline 5. & 06 & Merah & Hijau & Berhasil \\
\hline 6. & 12 & Merah & Hijau & Berhasil \\
\hline 7. & 09 & Merah & Hijau & Berhasil \\
\hline 8. & 08 & Merah & Hijau & Berhasil \\
\hline 9. & 18 & Merah & Hijau & Berhasil \\
\hline 10. & 14 & Merah & &
\end{tabular}

Gambar 6 menunjukkan hasil dari pengujian perangkat lunak pada keypad, status area parkir yang berwarna merah menandakan area parkir masih kosong, sedangkan area parkir yang berwarna hijau menandakan area parkir telah terisi kendaraan.

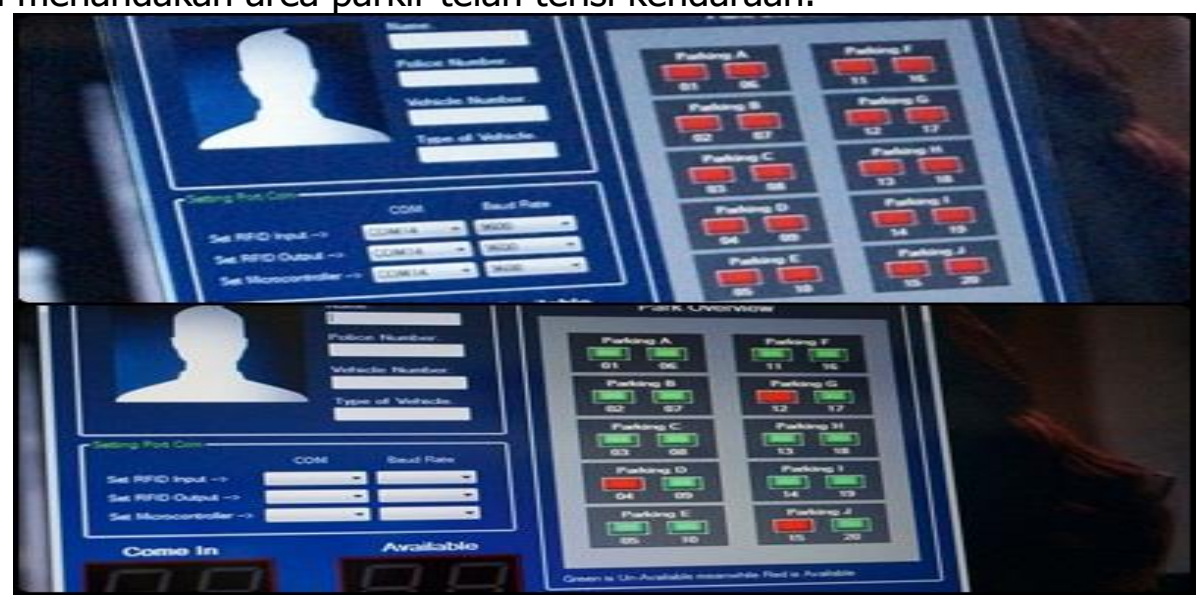

Gambar 6. Hasil Pengujian Perangkat Lunak keypad 
Dari Tabel 6 hasil pengujian keypad berhasil membuat warna area parkir pada tampilan area parkir pintu masuk menjadi berubah warnanya dari merah menjadi hijau yang berarti pemilihan lokasi parkir sesuai dengan penekan yang dilakukan pada keypad. Pada saat penekanan keypad apabila dimasukkan kembali lokasi yang telah dipilih tidak akan bisa mengubah warna dan juga tidak bisa membuka palang pintu dikarenakan sudah ada yang mengisi area tersebut.

\subsubsection{Pengujian Database}

Untuk database pada sistem yang dirancang digunakan Microsoft Acess. Saat pentag-an kartu RFId pengendara parkir akan melihat seluruh identitas yang ada pada kartu yang meliputi nama, nomor kendaraan, nomor identitas, alamat dan data-data yang telah didaftarkan sebelumnya. Database yang sudah ada pada kartu pengguna apartemen itu akan masuk kedalam database yang ada di ruang operator dan tersimpan. Begitu juga pengambilan gambar yang terjadi apabila pengguna lahan parkir meninggalkan area parkir akan tersimpan pada database di ruang opertator. Gambar 7 menunjukan hasil pengujian database yang tersimpan pada pada komputer server.

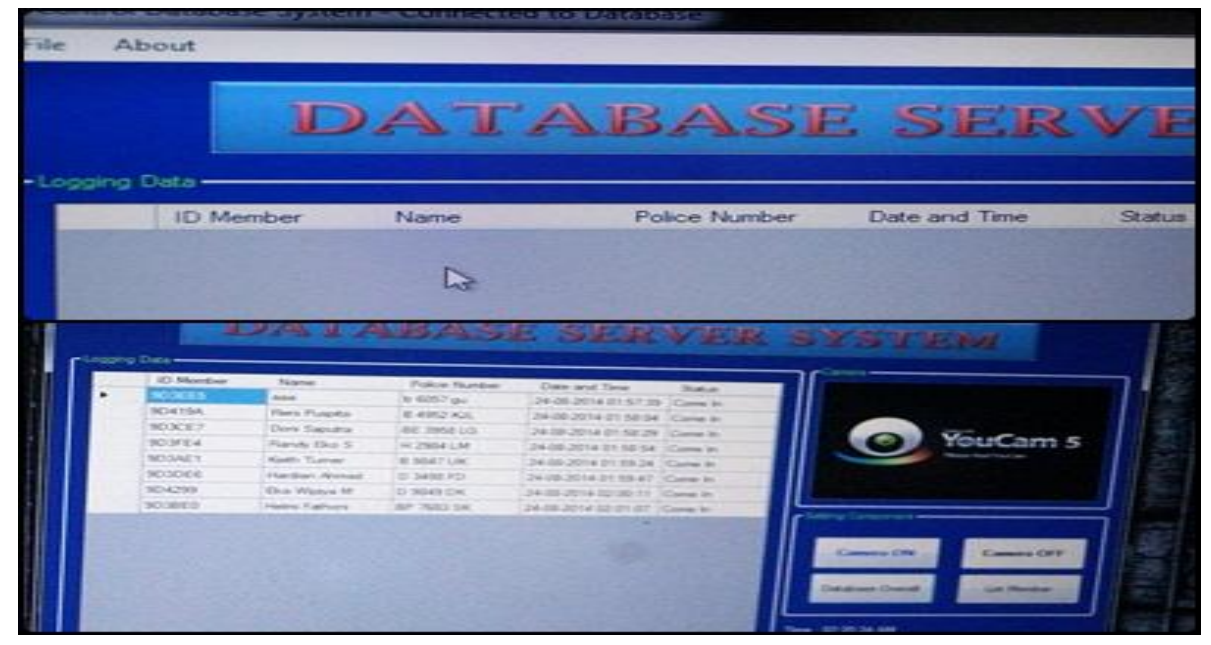

Gambar 7. Hasil Pengujian Database

\subsubsection{Pengujian Fungsional Sistem}

Pengujian fungsional sistem ini dilakukan untuk mengetahui kondisi keseluruhan sistem berjalan sempurna atau terjadi error pada saat sistem di oprasikan hasil pengujian dilakukan dalam keadaan normal.

\section{Kondisi normal}

Pengujian kondisi normal adalah pengujian dengan kondisi kendaraan di tempat parkir sesuai dengan area yang telah dipilih sebelumnya.

1. Tag RFId dan sistem perangkat keras seperti sensor, keypad dan servo terhubung

2. Power supply dinyalakan.

Gambar 8 menunjukkan miniatur sistem perparkiran yang dirancang dimana terdapat 20 blok area parkir yang dapat di akses oleh pemilik kendaraan. 


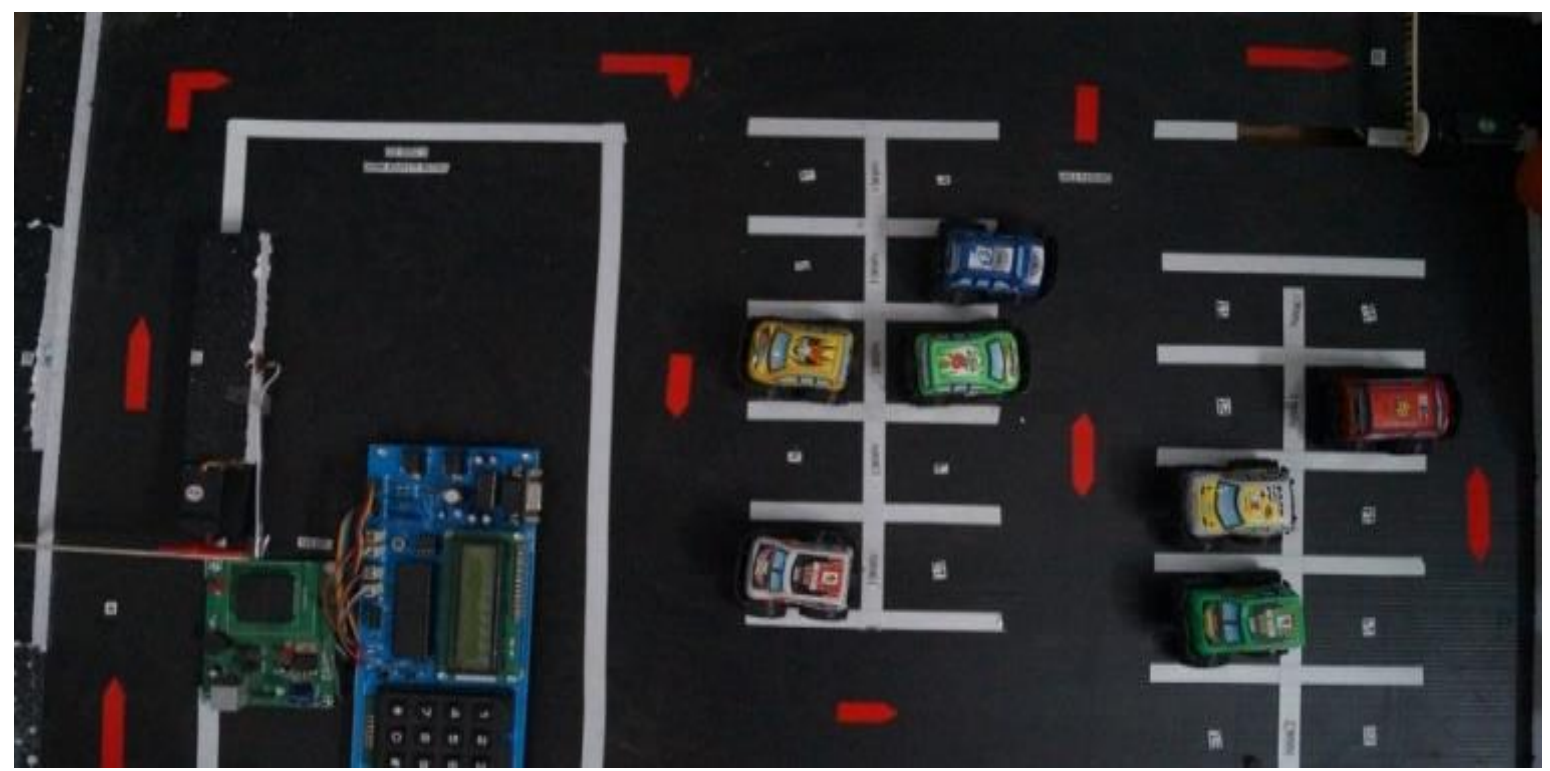

\section{Gambar 8. Miniatur Sistem Perparkiran}

Pada Sistem keseluruhan:

1. Program Parkir dijalankan

2. Display pada pintu masuk yang menunjukkan data pengakses area parkir yang sudah menjadi member serta lokasi parkir berwarna merah yang berarti masih ada tempat parkir yang belum terisi.

3. Pada layar tampak status blok parkir masih berwarna merah yang berarti seluruh area empat parkir masih kosong belum terisi (masih kosong). Gambar 9 menunjukkan seluruh area blok parkir masih kosong belum terisi.

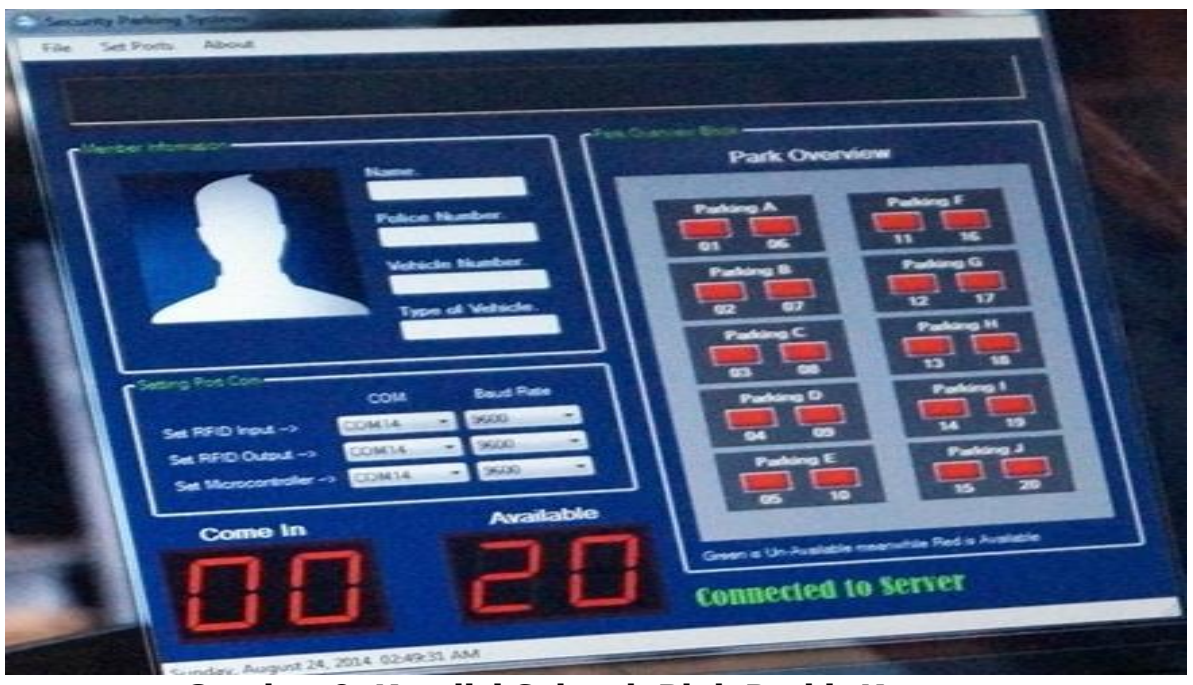

Gambar 9. Kondisi Seluruh Blok Parkir Kosong

4. Pada saat tombol pemilihan blok area parkir ditekan, blok area akan berubah warnanya menjadi hijau. Untuk kondisi blok area parkir setelah penekanan tombol dapat dilihat pada Gambar 10. 


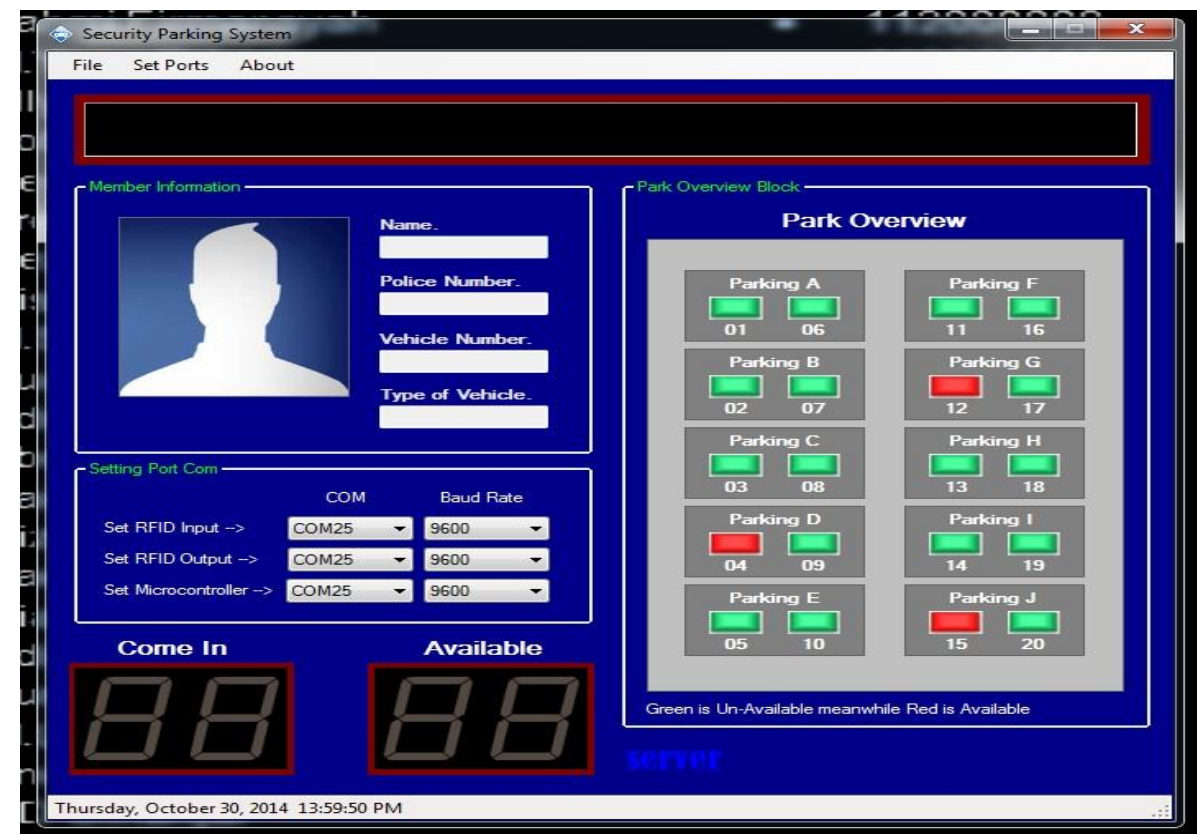

Gambar 10. Kondisi Blok Area Parkir Setelah dipilih

5. Database akan otomatis tersimpan pada ruang operator setelah pengguna area parkir mengakses lahan parkir dengan format id member, nama, police nummber, date and time serta status. Untuk file dari database yang disimpan dapat dilihat pada Gambar 11.

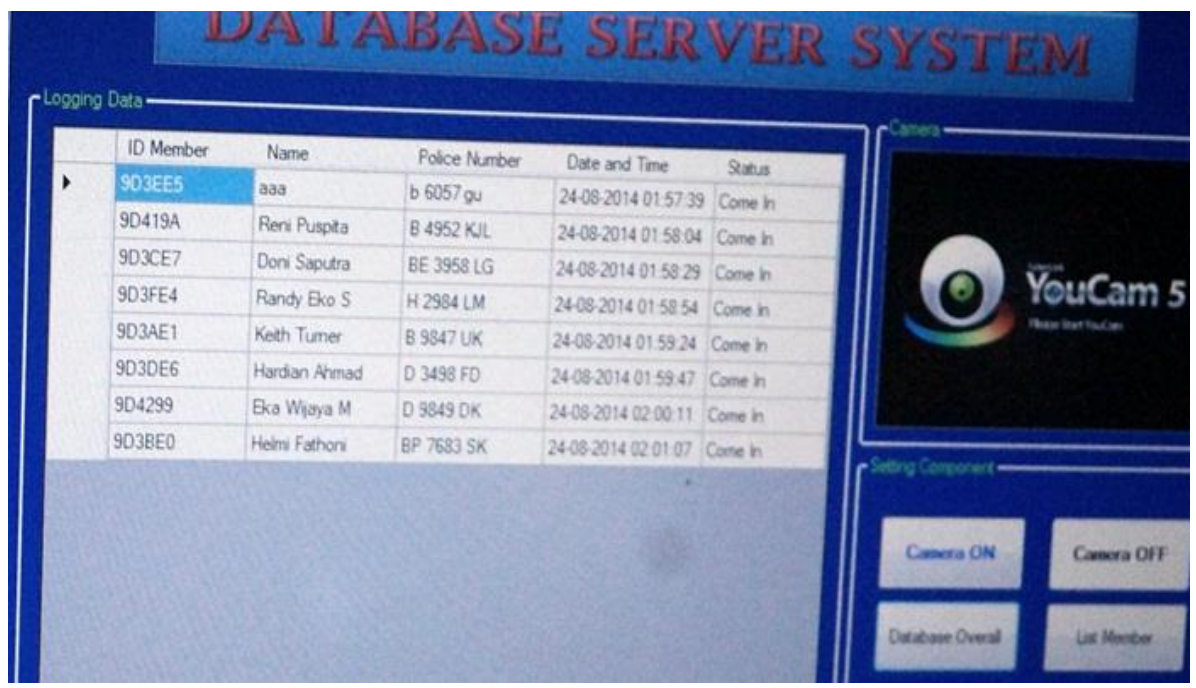

Gambar11. Database diruang Server

6. Saat kendaraan keluar akses area parkir, maka pengintregrasian kartu RFId kembali dilakuan ini untuk mencatat kondisi status di ruang operator dan akan mengambil gambar dari kamera web di pintu keluar dengan format nama penyimpanan waktu diambilnya gambar yaitu tahun-bulan-tanggal jam:menit:detik.bmp dengan resolusi 640x480 piksel. Untuk file dari gambar yang ditangkap dengan kamera dapat dilihat pada Gambar 12. 


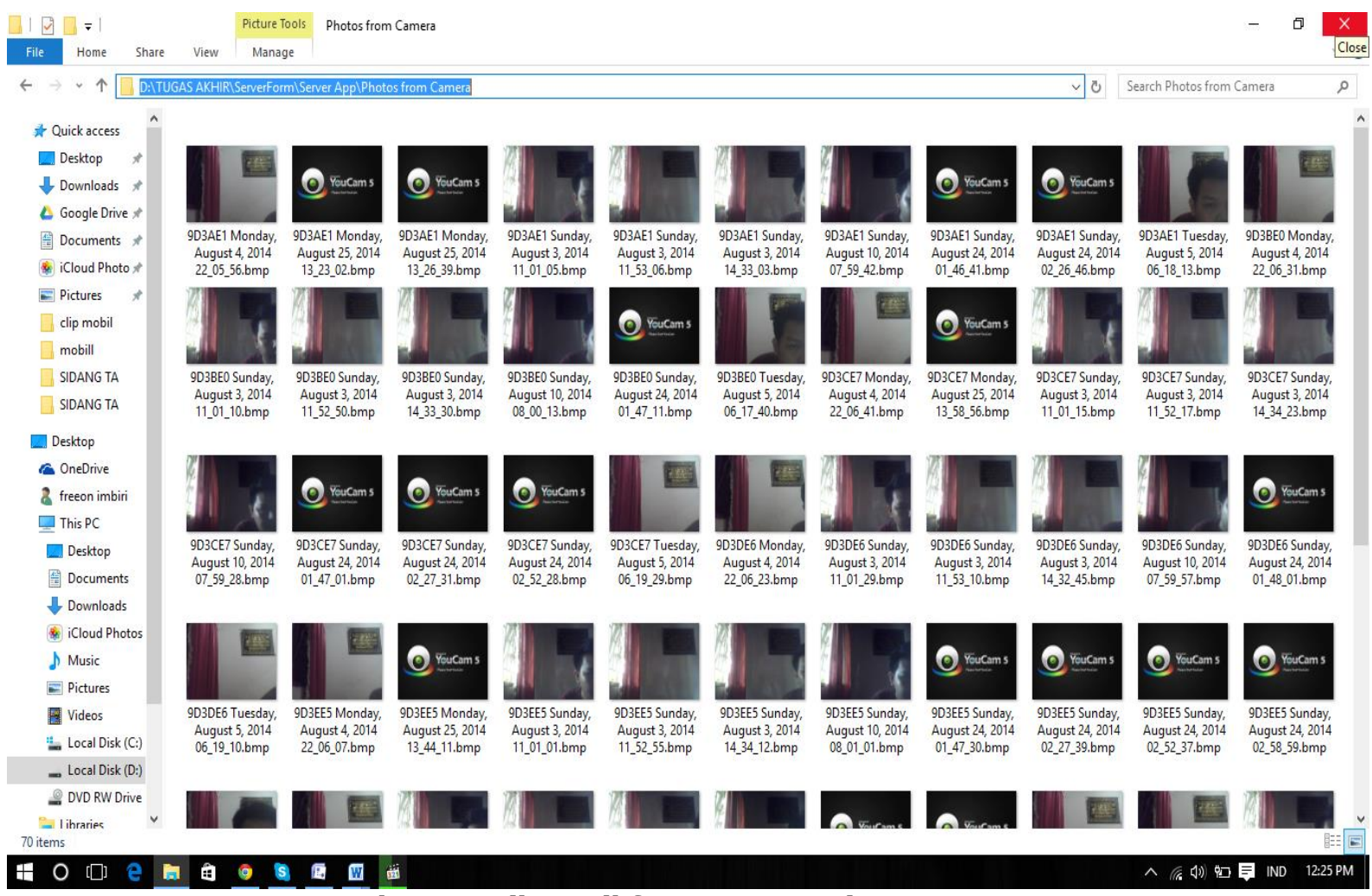

Gambar 12. File Hasil foto yang Tersimpan

7. Informasi jam keluar kendaraan, pengakses lahan parkir serta file gambar yang sudah mengakses dan meninggalkan area parkir akan otomatis ter-update pada file database di ruang operator.

\subsubsection{Pendaftaran Member Baru}

Pada pengujian pendaftaran member baru pengakses lahan parkir pada apartemen perlu dilakukan beberapa tahap pendaftaran yang dapat dilakukan. Saat pendaftaran pengguna kendaraan wajib memberikan beberapa data identitas seperti surat kendaraan, kartu identitas serta foto dari pengakses yang akan menggunakan lahan parkir.

Langkah-langkah pendaftaran member baru:

1. Pengguna kendaraan menyerahkan beberapa surat-surat kendaraan sebagai syarat utama untuk mengakases area parkir yang akan digunakan seperti kartu identitas, surat kendaraan serta foto. Dan kemudian akan didaftarkan dan tersimpan di dalam database setelah itu kartu diberikan dan siap digunakan oleh pengguna kendaraan. Gambar 13.menunjukan tampilan pendaftaran member baru yang siap diisi. 


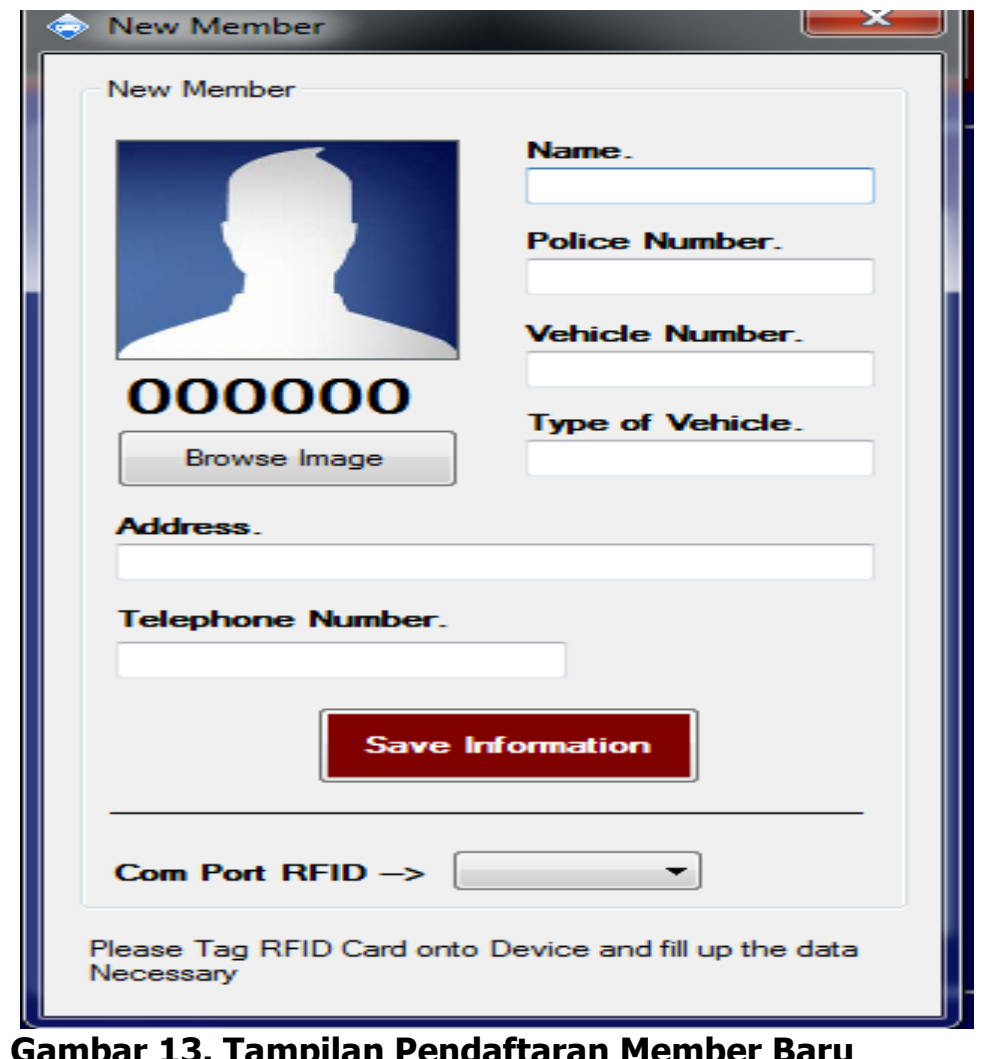

Gambar 13. Tampilan Pendaftaran Member Baru

2. File database yang tersimpan dalam bentuk microsoft acess pada ruang operator akan otomatis tersimpan apabila ada pendaftaran member baru. Gambar 14 menunjukkan Tabel database yang tersimpan pada microsoft acess.

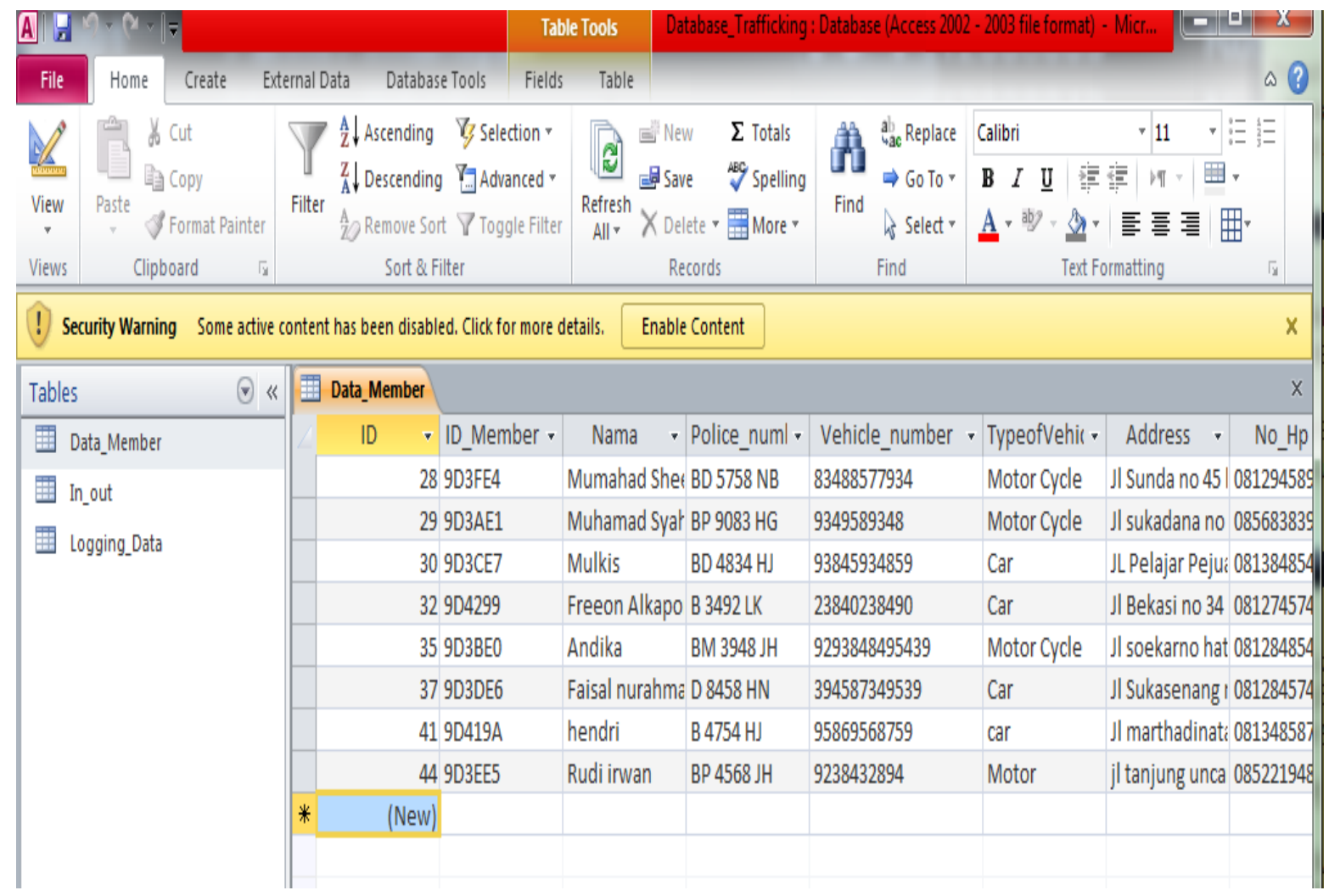

Gambar 14. Tabel Database Member Baru 


\section{KESIMPULAN}

Berdasarkan hasil perancangan, realisasi dan pengujian terhadap sistem perparkiran secara otomatis menggunakan teknologi RFId, maka dapat diambil beberapa kesimpulan sebagai berikut .

1. Cara pengkoneksian antara RFId, sistem keseluruhan parkir seta penempatan sensor pada setiap pintu masuk dan keluar area parkir dapat berfungsi dengan baik.

2. Penggunaan sensor LDR dapat berfungsi mendeteksi ada tidaknya kendaraan yang melewatinya dan sebagai input untuk menutup palang pintu yang menggunakan motor servo.

3. Berdasarkan pengujian perangkat keras sensor untuk interface, keypad berhasil difungsikan untuk berbagai hal, mengubah warna objek pada interface, menjadi trigger bagi motor servo untuk membuka palang pintu serta kamera web untuk mengambil gambar.

4. Pengambilan data yang dilakukan oleh kartu RFId secara continue membantu pengelola lahan parkir sehingga tidak perlu terus menerus menginputkan data kendaraan secara manual

5. RFId mampu jadi peranan sebagai pengendali sistem. Tidak hanya memproses inputan data yang langsung diterima pada saat pengkoneksian antar perangkat, tapi juga mampu menjalankan sistem database.

\section{DAFTAR RUJUKAN}

Landt, J. (2005). The History of RFID. IEEE Potensials. 24(4): 8-11.

Nath, B. (2006). RFID Technology and Applications. IEEE Pervasive Computing. 5(1): 2-24.

Want, Roy. (2004). Enabling Ubiquitous Sensing with RFID. Computer. 37(4): 84-86.

Darwin. (2014). Sistem Manajemen Parkir Menggunakan Teknologi Radio Frequency And Identification. Samarinda: Darwin Publisher.

Kurniawan, B., (2014). Perbaikan Sistem Parkir Kendaraan Bermotor Di Lingkungan Universitas Komputer Indonesia Dengan Menggunaan RFid Dan Database. Bandung: Kurniawan Publisher.

Winarsih, Irda; Mahendra, Reza. (2009). Sistem Parkir Otomatis Menggunakan RFid Berbasiskan Mikrokontroller AT89S51. Jakarta: Irda Publisher.

Sitanaya, R. L. (2005). Sistem Parkir Prabayar Menggunakan RFid Untuk Pusat Perbelanjaan. Surabaya: Sitanaya Publisher. 